\title{
EXPERIMENTAL STUDY OF PEAT HUMIFICATION INDICATORS
}

\author{
Jānis Šīre, Māris Kḷaviṇš, Oskars Purmalis, and Viesturs Melecis
}

Department of Environmental Science, University of Latvia, Raiṇa bulv. 19, LV-1586, Rīga, LATVIA

Contributed by Māris Kḷaviṇš

An important parameter of organic matter in soils, peat, and fossil-carbon-containing deposits is their decomposition degree, which describes their transformation intensity-the humification degree of original living organic matter. In this article approaches to the analysis of humification degree are thoroughly described and ${ }^{14} \mathrm{C}$ dated peat columns extracted from several bogs in Latvia are investigated and compared. A new humification indicator is suggested: the ratio of the total amount of organic matter in peat in respect to the amount of humic substances.

Key words: peat, humification degree, decomposition degree, chemical analysis.

\section{INTRODUCTION}

Natural organic matter (NOM) forms a major part of soil, sediment, peat, and fossil fuel organic matter and comprises the largest pool of carbon on the Earth (Schimel et al., 1997). NOM consists (Piccolo, 2001) of organic material in the following phases: a) partially degraded, but still identifiable plant tissues; b) microbial biomass; c) organic coatings of mineral phases; d) still identifiable organic substances of low molecular weight; and e) the refractory part of organic matter-humic substances (humic acid, fulvic acid, and humin). Historically, the term "humus" has been applied to the dark-coloured, organic matter in soils, and the terms "humic acid", "fulvic acid", and "humin" have been used to designate different portions of humus. Natural organic matter is the product of the decay of living organic matter formed in the following types of degradation reactions: a) biotic (enzymatically catalysed) reactions; b) pyrolytic reactions; and c) abiotic reactions exclusive of pyrolytic reactions (Lu et al., 2000). In line with these reactions, synthetic reactions in low molecular weight decay products are of definite importance. In the process of the decay, the bulk of living organic matter is mineralised and no more than $20 \%$ of its mass are transformed into refractory organic substances (Lukosko et al., 1988). Both degradation and synthetic processes in living organic matter are described as humification; in general, the term refers to the transformation of numerous groups of substances and individual molecules present in living organic matter into groups of substances with similar properties (humic substances) and, finally, into mineral carbon compounds. All these processes are important for understanding the carbon cycle and transformation processes of living matter. In this respect, the estimation of the extent of the humification process is of definite interest (Perez et al., 2004).

The understanding of the transformations of living organic matter down to their mineralisation, and especially the for- mation of humic substances (humification), is of key importance in understanding the carbon biogeochemical cycle (Francioso et al., 2003). Furthermore, the character of transformations of living organic matter does have impact on the structure and properties of humic substances. To characterise humification process, the development of humification indexes that link the rate of transformation of living organic matter and the development of humic substances with parameters describing the properties of the formed materials can be an important indicator (Lu et al., 2001).

Several humification indexes have been suggested to study the humification process during composting, in order to evaluate the maturity of compost (Jerzykiewicz et al., 1999; Domeizel et al., 2004) and to study soil formation processes (Zsolnay et al., 1999; Cavani et al., 2003; Ikeya and Watanabe, 2003; Rosa et al., 2005; Corvasce et al., 2006). Usually, the humification process is evaluated by making indirect measurements that describe structural changes, which occur during the humification process. Several methods have been suggested for description of humification, such as the measurement of $\mathrm{E}_{4} / \mathrm{E}_{6}$ ratio that indicates development of condensed macromolecules and the amount of organic/ aliphatic carbon estimated by ${ }^{13} \mathrm{C}$ CP MAS NMR. Also, the presence of free radicals, which is determined using EPR and the studies of fluorescence properties of humic macromolecules, has been used as a parameter of description of humification processes (Milori et al., 2002).

A significant amount of organic matter is stored as the organic matter of peat (Fuchsman, 1980). However, few studies on humification processes of peat have been conducted (Schnitzer and Levesque, 1979; Preston et al., 1989; Hargitai, 1994; Baran, 2002; Francioso et al., 2003), although bogs and wetlands form one of the largest sources of refractory organic matter.

The aim of this article is to study the humification process of peat and finding out the best indicators for the characteri- 
sation of humification process, to identify links between peat age (its decomposition degree) and the basic properties of peat and the organic matter of peat.

\section{MATERIALS AND METHODS}

Sampling. 28 peat samples were collected from the profiles of five raised bogs of industrial importance in Latvia. The profiles were obtained in varying depths from 0 to $145 \mathrm{~cm}$. The peat samples were dried in laboratory conditions at $105{ }^{\circ} \mathrm{C}$. The samples were then homogenised and sieved through a $1 \mathrm{~mm}$ sieve.

Materials. Analytical quality reagents (Merck Co., SigmaAldrich Co., Fluka Chemie AG RdH Laborchemikalien $\mathrm{GmbH}$ Co.) were used without further purification.

Peat characterisation. The basic characteristics of the peat samples are displayed in Table 1.

The analysis of botanical composition was performed using a Carl-Zeiss binocular microscope. The decomposition degree (von Post, 1924; Lishtvan and Korol, 1975) was determined using known methods. The ${ }^{14} \mathrm{C}$ dating was conducted at the Institute of Geology of the Tallinn Technical University (Estonia). Elemental analysis $(\mathrm{C}, \mathrm{H}, \mathrm{N}, \mathrm{S}$, and O) was carried out using an Elemental Analyzer Model EA-1108 (Carlo Erba Instruments). Ash content was measured after heating $50 \mathrm{mg}$ of each peat sample at $750{ }^{\circ} \mathrm{C}$ for
8 h. Metals (Na, Mg, K, Ca, Mn, Fe, Ni, Cu, Zn, Cd, Pb) were determined after wet digestion with $\mathrm{HNO}_{3}+\mathrm{HClO}_{4}$ (Tan, 2005). Metal concentrations were measured by flame atomic absorption (Perkin-Elmer AAnalyst 200). UV/Vis spectra were recorded on a Thermospectronic Helios $\gamma$ UV (Thermoelectron Co) spectrophotometer in a $1-\mathrm{cm}$ quartz cuvette. The ratios $\mathrm{E}_{2} / \mathrm{E}_{6}, \mathrm{E}_{2} / \mathrm{E}_{3}, \mathrm{E}_{3} / \mathrm{E}_{4}, \mathrm{E}_{4} / \mathrm{E}_{6}$ (Chen et al., 1977): ratio of absorbance at 280,340, 465 and $665 \mathrm{~nm}$ was determined for the solution of $5 \mathrm{mg}$ of the humic or fulvic acid in $10 \mathrm{ml}$ of $0.05 \mathrm{M} \mathrm{NaHCO}_{3}$. Organic carbon concentration of peat extracts was determined and Shimadzu TOC-VCSN. For carbohydrate analysis, humic samples $(10 \mathrm{mg}$ ) were suspended in $10 \mathrm{ml}$ of $6 \mathrm{M} \mathrm{HCl}$ and heated at $100 \mathrm{C}$ for 3 hours. In the hydrolysates, the concentration of carbohydrates was determined using phenol-sulphuric acid assay following the method described by Chaplin and Kennedy (1994). Cation exchange capacity (ammonium acetate method) and concentration of phosphates were determined using methods suggested for soil analysis (Tan, 2005). pH was determined in demineralised water extracts using a $\mathrm{pH}$ meter Hanna pH 213 (Tan, 2005).

Estimation of humification indicators. Humification index (HI) (Cavani et al., 2003). $2.0 \mathrm{~g}$ of peat sample in a 250 $\mathrm{ml}$ flask was extracted under shaking with $100 \mathrm{ml}$ of $0.1 \mathrm{M}$ $\mathrm{NaOH}$ plus $0.1 \mathrm{M} \mathrm{Na}_{4} \mathrm{P}_{2} \mathrm{O}_{7}$ for $48 \mathrm{~h}$ at $65^{\circ} \mathrm{C}$ in a thermostated shaker (Biosan, Latvia) under $\mathrm{N}_{2}$ atmosphere. After the extraction the samples were centrifuged at $5000 \mathrm{rpm}$ for

Table 1

BASIC CHARACTERISTICS OF THE PEAT SAMPLES

\begin{tabular}{|c|c|c|c|c|c|}
\hline Sample & Depth, cm & Peat type & Peat age, years & Decomposition, $\mathrm{H}$ & Decomposition, $\%$ \\
\hline Ploce 0-30 & $0-30$ & Raised bog fuscum peat & 1460 & $\mathrm{H} 5$ & 24 \\
\hline Ploce $30-60$ & $31-60$ & Raised bog fuscum peat & n.d. & H1 & 8 \\
\hline Ploce $60-85$ & $61-85$ & Raised bog fuscum peat & 1560 & $\mathrm{H} 2$ & 14 \\
\hline Ploce $85-110$ & $86-110$ & Raised bog fuscum peat & n.d. & $\mathrm{H} 2$ & 14 \\
\hline Ploce $110-130$ & $111-130$ & Raised bog cotton-grass - sphagnum peat & 1670 & $\mathrm{H} 2$ & 11 \\
\hline Gāgu 0-20 & $0-20$ & Raised bog cotton-grass - sphagnum peat & n.d. & H6 & 29 \\
\hline Gāgu 20-40 & $21-40$ & Raised bog cotton-grass - sphagnum peat & n.d. & H6 & 32 \\
\hline Gāgu 40-60 & $41-60$ & Raised bog cotton-grass - sphagnum peat & n.d. & H6 & 31 \\
\hline Gāgu 60-80 & $61-80$ & Raised bog fuscum peat & n.d. & $\mathrm{H} 2$ & 20 \\
\hline Gāgu 80-100 & $81-100$ & Raised bog fuscum peat & n.d. & $\mathrm{H} 2$ & 13 \\
\hline Gāgu 100-120 & $101-120$ & Raised bog fuscum peat & n.d. & $\mathrm{H} 2$ & 13 \\
\hline Gāgu 120-140 & $121-140$ & Raised bog fuscum peat & 1640 & $\mathrm{H} 2$ & 11 \\
\hline Kaigu 0-25 & $0-25$ & Raised bog cotton-grass - sphagnum peat & 810 & H6 & 33 \\
\hline Kaigu $25-45$ & $26-45$ & Raised bog fuscum peat & n.d. & $\mathrm{H} 2$ & 10 \\
\hline Kaigu $45-70$ & $46-70$ & Raised bog fuscum peat & 1590 & $\mathrm{H} 2$ & 11 \\
\hline Kaigu 70-95 & $71-95$ & Raised bog narrow-leaf sphagnum peat & n.d. & $\mathrm{H} 2$ & 33 \\
\hline Kaigu 95-125 & $96-125$ & Raised bog narrow-leaf sphagnum peat & n.d. & $\mathrm{H} 1$ & 7 \\
\hline Kaigu 125-145 & $126-145$ & Raised bog fuscum peat & 2260 & $\mathrm{H} 2$ & 9 \\
\hline Dižais Veiķenieks 0-25 & $0-25$ & Raised bog fuscum peat & 520 & $\mathrm{H} 2$ & 12 \\
\hline Dižais Veiķenieks 25-52 & $26-52$ & Raised bog fuscum peat & n.d. & $\mathrm{H} 2$ & 12 \\
\hline Dižais Veiķenieks 52-75 & $53-75$ & Raised bog fuscum peat & 980 & $\mathrm{H} 2$ & 6 \\
\hline Dižais Veiķenieks 75-98 & $76-98$ & Raised bog fuscum peat & n.d. & $\mathrm{H} 2$ & 9 \\
\hline Dižais Veiķenieks 98-118 & $99-118$ & Raised bog fuscum peat & 1350 & $\mathrm{H} 1$ & 6 \\
\hline Mazais Veiķenieks 0-30 & $0-30$ & Raised bog fuscum peat & 400 & $\mathrm{H} 2$ & 8 \\
\hline Mazais Veiķenieks 30-60 & $31-60$ & Raised bog Magellan's sphagnum peat & n.d. & $\mathrm{H} 3$ & 14 \\
\hline Mazais Veiķenieks 60-90 & $61-90$ & Transition type tree - grass peat & n.d. & H5 & 27 \\
\hline Mazais Veik̦enieks 90-125 & $91-125$ & Low type tree - grass peat & 1180 & H6 & 31 \\
\hline
\end{tabular}


$15 \mathrm{~min}$ and the supernatants were filtered through a $1 \mu \mathrm{m}$ filter. This filtered solution constituted the total extract (TE) and was fractionated into humified (humic acids HA, fulvic acids FA) and non-humified (NH) fractions. In short, $25 \mathrm{ml}$ of TE was put into a $50 \mathrm{ml}$ centrifuge tube and acidified to $\mathrm{pH}<2$ by adding a small volume $(0.3-0.5 \mathrm{ml})$ of $9 \mathrm{M}$ $\mathrm{H}_{2} \mathrm{SO}_{4}$, then centrifuged at $5000 \mathrm{~g}$ for 20 minutes. The precipitated fraction (HA) was collected and stored, and the supernatant solution fed onto a small column packed with about $5 \mathrm{~cm}^{3}$ of insoluble polyvinylpyrrolidone, previously equilibrated in $0.005 \mathrm{M} \mathrm{H}_{2} \mathrm{SO}_{4}$. The eluate $(\mathrm{NH})$ was collected in a $50 \mathrm{ml}$ volumetric flask, then diluted to volume with $0.005 \mathrm{M} \mathrm{H}_{2} \mathrm{SO}_{4}$ and stored. The retained fraction (FA) was eluted with $0.5 \mathrm{M} \mathrm{NaOH}$ solution and collected in the centrifuge tube containing the HA precipitate, which was redissolved. Total organic carbon (TOC) and humified carbon (HA, FA) were determined using a TOC analyser as described elsewhere. The humification index (HI) was calculated as follows:

$H I=\frac{C_{N H}}{C_{H A}+C_{F A}}$.

Pyrophosphate index (PyI) (Schnitzer and Levesque, 1979). $0.50 \mathrm{~g}$ of peat sample was shaken for $18 \mathrm{hrs}$ with $50 \mathrm{ml}$ of $0.025 \mathrm{M} \mathrm{Na}_{4} \mathrm{P}_{2} \mathrm{O}_{7}$ at room temperature. The peat residue was separated by filtration, washed with distilled water, and the filtrates with washings were diluted to $250 \mathrm{ml}$ with distilled water. The optical density of this solution was measured at $550 \mathrm{~nm}$ and absorbance multiplied by 100 was referred to as pyrophosphate index PyI.

$P y I=D_{550} \times 100$.

Humus quality K value (Hargitai 1994). $1.00 \mathrm{~g}$ of peat sample was shaken for $6 \mathrm{hrs}$ with $50 \mathrm{ml}$ of $1 \% \mathrm{NaF}$, filtered, and in the filtrate the adsorption at $410 \mathrm{~nm}\left(\mathrm{D}_{\mathrm{HSNaF}}\right)$ was determined. Another $1.00 \mathrm{~g}$ portion of the same peat sample was extracted shaking for $6 \mathrm{hrs}$ with $50 \mathrm{ml}$ of $0.5 \% \mathrm{NaOH}$, filtered, and in the filtrate adsorption at $410 \mathrm{~nm}\left(\mathrm{D}_{\mathrm{HSNaOH}}\right)$ was determined.

The humus quality value $\mathrm{K}$ was calculated as:

$K=\frac{D_{H S N a F}}{D_{H S N a O H}} \times C$,

where $\mathrm{C}$ is the percentage of carbon in the sample.

Peat humification index (PHI). $1.00 \mathrm{~g}$ of peat sample was shaken for $24 \mathrm{hrs}$ with $50 \mathrm{ml}$ of deionised water, filtered, and in the filtrate the total organic carbon of the aquatic extract $\left(\mathrm{C}_{\mathrm{w}}\right)$ was determined. Another $1.00 \mathrm{~g}$ portion of the same peat sample was extracted shaking for $24 \mathrm{hrs}$ with 50 $\mathrm{ml}$ of $0.1 \mathrm{M} \mathrm{NaOH}$, filtered, and in the filtrate the total organic carbon of the alkaline extract $\left(\mathrm{C}_{\mathrm{NaOH}}\right)$ was determined. The peat humification index was calculated as:

$P H I=\frac{C_{w}}{C_{\mathrm{NaOH}}} \times 100$.
Humification degree (HD). $1.00 \mathrm{~g}$ of peat sample was shaken for $24 \mathrm{hrs}$ with $50 \mathrm{ml}$ of $1.0 \mathrm{M} \mathrm{NaOH}$, filtered, and in the filtrate the total organic carbon of the alkaline extract, containing humic substances $\left(\mathrm{C}_{\mathrm{HS}}\right)$, was determined $(\mathrm{mg}$ $\mathrm{C} / \mathrm{g})$. The peat humification degree was calculated as:

$H D=\frac{C_{H S}}{C_{\text {peat }}} \times 100$,

where $\mathrm{C}$ is the percentage of carbon in the sample $(\mathrm{mg} / \mathrm{g})$.

Data analysis. Principal component analysis (PCA) (rotation method: Varimax with Kaiser Normalization (rotation converged in eight iterations)) was conducted using SPSS 12.0 for Windows.

\section{RESULTS}

In this study peat from five raised bogs of industrial importance in Latvia was used. Samples from different depths were obtained, representing bogs which reflect bog development conditions in Northern Europe. The botanical composition of the deepest layer of peat was mostly raised bog cotton-grass-sphagnum peat and fuscum peat, while upper layer was raised bog fuscum peat. The age of the samples varied from 400 to 2260 years, and their decomposition degree (von Post scale) varied from H2 to H6 (Table 1). In all obtained peat samples their elemental composition has been determined (Table 2).

Table 2

ELEMENTAL COMPOSITION OF THE STUDIED PEAT SAMPLES

\begin{tabular}{l|c|c|c|c|c}
\hline \multicolumn{1}{c|}{ Sample } & $\mathrm{C}, \%$ & $\mathrm{H}, \%$ & $\mathrm{~N}, \%$ & $\mathrm{~S}, \%$ & $\mathrm{O}, \%$ \\
\hline Ploce 0-30 & 50.78 & 5.18 & 1.38 & 0.69 & 37.78 \\
Ploce 30-60 & 54.26 & 5.73 & 1.08 & 0.44 & 36.19 \\
Ploce 60-85 & 48.46 & 5.34 & 0.65 & 0.79 & 43.72 \\
Ploce 85-110 & 52.41 & 5.31 & 1.05 & 0.67 & 39.87 \\
Ploce 110-130 & 52.18 & 5.16 & 0.79 & 0.63 & 40.70 \\
Gāgu 0-20 & 48.54 & 5.54 & 1.15 & 0.84 & 40.79 \\
Gāgu 20-40 & 49.09 & 5.67 & 0.93 & 1.34 & 43.06 \\
Gāgu 40-60 & 48.82 & 5.60 & 0.75 & 0.58 & 43.86 \\
Gāgu 60-80 & 48.41 & 5.62 & 0.68 & 0.52 & 44.62 \\
Gāgu 80-100 & 49.45 & 5.52 & 0.83 & 0.92 & 43.28 \\
Gāgu 100-120 & 49.68 & 5.49 & 0.73 & 0.67 & 43.23 \\
Gāgu 120-140 & 50.78 & 5.60 & 0.85 & 1.01 & 42.09 \\
Kaigu 0-25 & 48.26 & 5.76 & 1.15 & 0.69 & 41.57 \\
Kaigu 25-45 & 49.31 & 5.76 & 0.85 & 1.01 & 43.39 \\
Kaigu 45-70 & 49.56 & 5.71 & 0.80 & 0.77 & 43.16 \\
Kaigu 70-95 & 48.53 & 5.83 & 0.86 & 0.81 & 43.97 \\
Kaigu 95-125 & 48.54 & 5.59 & 0.78 & 0.72 & 44.44 \\
Kaigu 125-145 & 41.75 & 4.96 & 0.70 & 0.67 & 51.73 \\
Dižais Veik̦enieks 0-25 & 46.85 & 5.39 & 0.59 & 0.89 & 46.23 \\
Dižais Veik̦enieks 25-52 & 48.19 & 5.53 & 0.66 & 0.58 & 44.88 \\
Dižais Veiķenieks 52-75 & 47.53 & 5.52 & 0.45 & 0.53 & 45.82 \\
Dižais Veiķenieks 75-98 & 46.96 & 5.40 & 0.41 & 0.58 & 46.52 \\
Dižais Veiķenieks 98-118 & 46.72 & 5.47 & 0.43 & 0.81 & 46.92 \\
Mazais Veiķenieks 0-30 & 45.67 & 5.65 & 0.73 & 0.69 & 46.87 \\
Mazais Veiķenieks 30-60 & 46.49 & 5.80 & 0.53 & 0.54 & 45.87 \\
Mazais Veiķenieks 60-90 & 52.46 & 6.15 & 1.88 & 1.08 & 37.19 \\
Mazais Veiķenieks 90-125 & 53.01 & 6.09 & 2.38 & 0.94 & 35.37
\end{tabular}


The age and decomposition degree of peat gradually increases with increasing depth (Fig. 1).

However, the basic parameters of peat do not display a similar increasing trend for all the studied samples (Table 2). Carbon and nitrogen content of peat samples from the bog Mazais Veikienieks increases with increasing age (the depth and decomposition degree), but the content of sulphur decreases with increasing age. However, for the other studied bogs, the variability of elemental composition is not so random and most probably depends on the botanical composition and the specific peat formation conditions (mostly, the hydrological regime in the bog).

Not only peat basic characterisation (elemental composition), but also study of changes of properties, reflecting character of humification process has been done (Table 3).

The impact of peat development conditions on peat properties is also evident from the carbohydrate concentration,

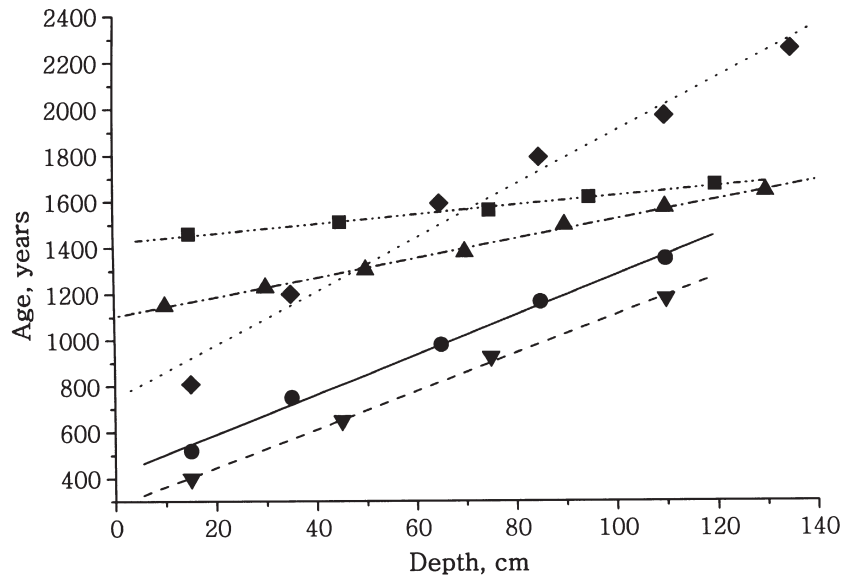

Fig. 1. Relationship between peat sample age and depth of their location. Dižais Veiķenieks peat bog; $\Delta$ Gāgu peat bog; $\bullet$ Kaigu peat bog; Ploce peat bog; $\boldsymbol{\nabla}$ Mazais Veikenieks peat bog.

COMPOSITION OF THE STUDIED PEAT SAMPLES

\begin{tabular}{|c|c|c|c|c|c|c|c|c|c|c|c|c|c|c|c|c|}
\hline Sample & $\mathrm{pH}$ & Ash, $\%$ & $\mid \begin{array}{c}\mathrm{CEC} \\
\mathrm{cmol}(+) / \mathrm{kg}\end{array}$ & 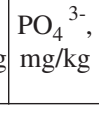 & $\begin{array}{c}\text { Carbo- } \\
\text { hydrates, } \\
\mathrm{mg} / \mathrm{g}\end{array}$ & $\begin{array}{c}\mathrm{Na}, \\
\mathrm{mg} / \mathrm{kg}\end{array}$ & $\begin{array}{c}\mathrm{Mg}, \\
\mathrm{mg} / \mathrm{kg}\end{array}$ & $\begin{array}{c}\mathrm{K}, \\
\mathrm{mg} / \mathrm{kg}\end{array}$ & $\begin{array}{c}\mathrm{Ca} \\
\mathrm{mg} / \mathrm{kg}\end{array}$ & $\begin{array}{c}\mathrm{Mn}, \\
\mathrm{mg} / \mathrm{kg}\end{array}$ & $\begin{array}{c}\mathrm{Fe}, \\
\mathrm{mg} / \mathrm{kg}\end{array}$ & $\begin{array}{c}\mathrm{Ni}, \\
\mathrm{mg} / \mathrm{kg}\end{array}$ & $\begin{array}{c}\mathrm{Cu}, \\
\mathrm{mg} / \mathrm{kg}\end{array}$ & $\begin{array}{c}\mathrm{Zn}, \\
\mathrm{mg} / \mathrm{kg}\end{array}$ & $\begin{array}{c}\mathrm{Cd}, \\
\mathrm{mg} / \mathrm{kg}\end{array}$ & $\begin{array}{c}\mathrm{Pb} \\
\mathrm{mg} / \mathrm{kg}\end{array}$ \\
\hline Ploce 0-30 & 2.95 & 5.18 & 13.8 & 0.69 & 37.78 & 66 & 584 & 109 & 7483 & 6.51 & 659 & 1.16 & 2.42 & 8.94 & 0.07 & 4.76 \\
\hline Ploce $30-60$ & 2.46 & 5.73 & 10.8 & 0.44 & 36.19 & 63 & 639 & 66 & 2590 & 2.74 & 534 & 0.97 & 2.12 & 16.67 & 0.30 & 15.86 \\
\hline Ploce $60-85$ & 2.51 & 5.34 & 6.5 & 0.79 & 43.72 & 69 & 632 & 54 & 2628 & 2.92 & 279 & 0.55 & 1.17 & 11.38 & 0.07 & 5.61 \\
\hline Ploce 85-110 & 2.40 & 5.31 & 10.5 & 0.67 & 39.87 & 72 & 886 & 27 & 1434 & 0.91 & 146 & 0.31 & 0.60 & 2.02 & 0.01 & 0.69 \\
\hline Ploce $110-130$ & 2.50 & 5.16 & 7.9 & 0.63 & 40.70 & 61 & 961 & 51 & 1984 & 5.06 & 168 & 0.32 & 2.00 & 2.42 & 0.04 & 0.79 \\
\hline Gāgu 0-20 & 2.50 & 5.54 & 11.5 & 0.84 & 40.79 & 60 & 502 & 165 & 1726 & 15.15 & 756 & 1.23 & 3.37 & 29.38 & 0.58 & 27.74 \\
\hline Gāgu 20-40 & 2.47 & 5.67 & 9.3 & 1.34 & 43.06 & 81 & 389 & 67 & 813 & 6.44 & 185 & 0.33 & 0.64 & 8.51 & 0.06 & 3.88 \\
\hline Gāgu 40-60 & 2.41 & 5.60 & 7.5 & 0.58 & 43.86 & 74 & 372 & 65 & 523 & 2.00 & 147 & 0.33 & 0.76 & 4.56 & 0.05 & 6.31 \\
\hline Gāgu 60-80 & 2.36 & 5.62 & 6.8 & 0.52 & 44.62 & 82 & 437 & 68 & 522 & 2.55 & 141 & 0.27 & 0.77 & 3.94 & 0.03 & 0.70 \\
\hline Gāgu 80-100 & 2.46 & 5.52 & 8.3 & 0.92 & 43.28 & 83 & 365 & 86 & 453 & 2.01 & 130 & 0.25 & 0.69 & 3.30 & 0.03 & 0.96 \\
\hline Gāgu 100-120 & 2.42 & 5.49 & 7.3 & 0.67 & 43.23 & 77 & 363 & 79 & 425 & 0.73 & 106 & 0.23 & 0.78 & 2.19 & 0.02 & 0.59 \\
\hline Gāgu 120-140 & 2.45 & 5.60 & 8.5 & 1.01 & 42.09 & 80 & 373 & 72 & 506 & 1.72 & 113 & 0.33 & 1.24 & 2.20 & 0.03 & 1.18 \\
\hline Kaigu 0-25 & 3.02 & 5.76 & 11.5 & 0.69 & 41.57 & 64 & 558 & 202 & 1786 & 17.31 & 566 & 1.08 & 2.00 & 13.39 & 0.18 & 10.78 \\
\hline Kaigu 25-45 & 3.07 & 5.76 & 8.5 & 1.01 & 43.39 & 51 & 250 & 80 & 443 & 0.86 & 113 & 0.23 & 0.49 & 2.09 & 0.03 & 0.42 \\
\hline Kaigu $45-70$ & 3.11 & 5.71 & 8.0 & 0.77 & & 54 & & 74 & & & & & & 3.71 & 0.03 & 0.98 \\
\hline Kaigu 70-95 & 3.15 & 5.83 & 8.6 & 0.81 & 43.97 & 62 & 313 & 83 & 476 & 1.22 & 109 & 0.29 & 0.63 & 3.25 & 0.27 & 0.84 \\
\hline Kaigu 95-125 & 3.26 & 5.59 & 7.8 & 0.72 & 44.44 & 47 & 359 & 63 & 424 & 1.03 & 83 & 0.20 & 0.55 & 2.46 & 0.01 & 0.40 \\
\hline Kaigu 125-145 & 3.31 & 4.96 & 7.0 & 0.67 & 51.73 & 34 & 665 & 54 & 782 & 2.70 & 127 & 0.19 & 0.71 & 2.26 & 0.01 & 0.33 \\
\hline $\begin{array}{l}\text { Dižais Veiķenieks } \\
0-25\end{array}$ & 2.94 & 5.39 & 5.9 & 0.89 & 46.23 & 81 & 507 & 94 & 704 & 6.98 & 115 & 0.35 & 0.59 & 5.84 & 0.05 & 5.53 \\
\hline $\begin{array}{l}\text { Dižais Veiķenieks } \\
25-52\end{array}$ & 2.90 & 5.53 & 6.6 & 0.58 & & 80 & & 90 & & & 95 & 0.18 & 0.44 & 2.67 & 0.02 & 3.04 \\
\hline $\begin{array}{l}\text { Dižais Veiķenieks } \\
52-75\end{array}$ & 2.28 & 5.52 & 4.5 & 0.53 & 45.82 & 115 & 336 & 99 & 414 & 0.77 & 120 & 0.08 & 0.53 & 2.48 & 0.01 & 0.55 \\
\hline $\begin{array}{l}\text { Dižais Veiķenieks } \\
75-98\end{array}$ & 2.29 & 5.40 & 4.1 & 0.58 & & 102 & 333 & 81 & & 0.98 & & 0.12 & 0.31 & 2.57 & 0.02 & 0.23 \\
\hline $\begin{array}{l}\text { Dižais Veiķenieks } \\
98-118\end{array}$ & 2.35 & 5.47 & 4.3 & 0.81 & 46.92 & 90 & 465 & 69 & 973 & 2.36 & 352 & 0.12 & 0.47 & 3.22 & 0.03 & 0.36 \\
\hline $\begin{array}{l}\text { Mazais Veikenieks } \\
0-30\end{array}$ & 3.01 & 5.65 & 7.3 & 0.69 & 46.87 & 51 & 456 & 54 & 1058 & 1.55 & 398 & 0.17 & 1.14 & 3.45 & 0.02 & 2.43 \\
\hline $\begin{array}{l}\text { Mazais Veiķenieks } \\
\text { 30-60 }\end{array}$ & 3.14 & 5.80 & 5.3 & 0.54 & 45.87 & 30 & 445 & 43 & 2191 & 2.00 & 665 & 0.51 & 2.11 & 2.68 & 0.01 & 2.63 \\
\hline $\begin{array}{l}\text { Mazais Veik,enieks } \\
60-90\end{array}$ & 3.66 & 6.15 & 18.8 & 1.08 & 37.19 & 28 & 352 & 73 & 3051 & 5.58 & 1503 & 1.24 & 1.50 & 4.34 & 0.03 & 4.60 \\
\hline $\begin{array}{l}\text { Mazais Veikenieks } \\
90-125\end{array}$ & 4.17 & 6.09 & 23.8 & 0.94 & 35.37 & 26 & 387 & 51 & 4473 & 6.48 & 2464 & 2.88 & 2.02 & 2.84 & 0.02 & 1.02 \\
\hline
\end{tabular}


cation exchange capacity, and the metal concentration in the peat samples analysed (Table 3). The results of the extensive peat characterization have been used to study the impact of the peat formation conditions on the major peat properties and humification character of the peat organic matter.

\section{DISCUSSION}

Although knowledge of the transformation process of living organic matter (humification) is of importance in understanding of the carbon biogeochemical cycle, the number of studies dedicated to this topic is rather small (Jerzykiewicz et al., 1999; Zsolnay et al., 1999; Ikeya and Watanabe, 2003; Cavani et al., 2003; Domeizel et al., 2004; Rosa et al., 2005; Corvasce et al., 2006). Peat can be considered an especially appropriate subject of studies of humification because it is possible to establish links between the properties of peat and the decomposition degree of original organic matter. In addition, the studies of peat humification are of definite applied and theoretical interest.

To study the humification process, principal component analysis was used to determine the main factors affecting peat composition (Table 4, 5). Six principal components were extracted explaining $87 \%$ of the total variance of data (Table 4, 5). The six components define the main peat property factors: component 1 is characterised by depth of the peat layer, ash content, as well as the concentration of phosphate ions, carbohydrates and potassium (Table 5). Concentration of metals (mostly of anthropogenic origin, for example, $\mathrm{Cd}, \mathrm{Pb}$ ) in peat can be explained by this very component. Component 2 is associated with peat decomposition degree, ash content, carbon content, and also metals of, most likely, natural origin $(\mathrm{Ca}, \mathrm{Mg}, \mathrm{Fe})$; it can also be suggested that this factor describes peat genesis. Component 3 is associated with biogenic processes (presence of carbohydrates-abundant in living plants, but rapidly consumed during the decay process), presence of phosphate ions and nitrogen, and sodium. Component 4 is characterised by peat layer depth and age, component 5-by magnesium and calcium concentration and component 6-by sulphur content in peat and cation exchange capacity.

Table 4

SUMMARY STATISTICS OF PCA OF THE DATA ON THE SELECTED PEAT PROPERTIES*

\begin{tabular}{c|c|c|c}
\hline Component & Variance & $\begin{array}{c}\text { \% of explained } \\
\text { variance }\end{array}$ & $\begin{array}{c}\text { Cumulative \% of } \\
\text { variance }\end{array}$ \\
\hline 1 & 6.064 & 24.254 & 24.254 \\
2 & 5.020 & 20.081 & 44.335 \\
3 & 4.841 & 19.365 & 63.699 \\
4 & 2.248 & 8.991 & 72.690 \\
5 & 2.138 & 8.552 & 81.242 \\
6 & 1.362 & 5.449 & 86.691
\end{tabular}

* VARIMAX rotation and Kaiser's normalisation were used on the initial component structure
Table 5

LOADING STRUCTURE OF THE FIRST SIX COMPONENTS EXTRACTED BY PCA ANALYSIS OF THE DATA ON THE SELECTED PEAT PROPERTIES

\begin{tabular}{|c|c|c|c|c|c|c|c|}
\hline \multirow{2}{*}{\multicolumn{2}{|c|}{ Variable/acronym }} & \multicolumn{6}{|c|}{ Component } \\
\hline & & 1 & 2 & 3 & 4 & 5 & 6 \\
\hline Type & PV1 & 0.006 & 0.393 & 0.761 & -0.042 & -0.255 & 0.084 \\
\hline Depth, cm & PV2 & -0.453 & 0.008 & 0.129 & -0.719 & 0.061 & 0.001 \\
\hline $\mathrm{C}, \%$ & PV3 & 0.022 & 0.912 & -0.132 & -0.229 & -0.107 & 0.082 \\
\hline $\mathrm{H}, \%$ & PV4 & 0.057 & 0.406 & 0.394 & 0.197 & -0.733 & 0.116 \\
\hline $\mathrm{N}, \%$ & PV5 & 0.172 & 0.763 & 0.498 & 0.051 & 0.017 & 0.256 \\
\hline $\mathrm{S}, \%$ & PV6 & 0.019 & 0.143 & 0.142 & -0.010 & -0.231 & 0.826 \\
\hline $\mathrm{O}, \%$ & PV7 & -0.233 & -0.948 & -0.051 & 0.057 & 0.011 & -0.095 \\
\hline Ash content, $\%$ & PV8 & 0.609 & 0.575 & 0.183 & 0.271 & 0.363 & -0.004 \\
\hline $\mathrm{pH}$ & PV9 & -0.073 & 0.174 & 0.913 & 0.162 & -0.047 & 0.146 \\
\hline $\mathrm{CEC}, \mathrm{mEq} / \mathrm{kg}$ & PV10 & 0.234 & -0.079 & -0.556 & 0.274 & -0.109 & -0.465 \\
\hline $\mathrm{PO}_{4}{ }^{3-}, \mathrm{mg} / \mathrm{kg}$ & PV11 & 0.557 & 0.229 & -0.675 & 0.125 & 0.311 & 0.026 \\
\hline $\begin{array}{l}\text { Carbohydrates, } \\
\mathrm{mg} / \mathrm{g}\end{array}$ & PV12 & 0.557 & 0.229 & -0.675 & 0.125 & 0.311 & 0.026 \\
\hline $\begin{array}{l}\text { Decomposition } \\
\text { degree }\end{array}$ & PV13 & 0.587 & 0.401 & 0.307 & 0.344 & 0.106 & 0.294 \\
\hline Age, years & PV14 & -0.055 & -0.035 & 0.001 & -0.860 & 0.228 & 0.068 \\
\hline $\mathrm{Na}, \mathrm{mg} / \mathrm{kg}$ & PV15 & -0.112 & -0.167 & -0.890 & 0.133 & -0.115 & -0.042 \\
\hline $\mathrm{Mg}, \mathrm{mg} / \mathrm{kg}$ & PV16 & 0.128 & 0.150 & -0.080 & -0.298 & 0.792 & -0.134 \\
\hline $\mathrm{K}, \mathrm{mg} / \mathrm{kg}$ & PV17 & 0.708 & -0.086 & -0.144 & 0.410 & -0.039 & 0.240 \\
\hline $\mathrm{Ca}, \mathrm{mg} / \mathrm{kg}$ & PV18 & 0.136 & 0.668 & 0.261 & 0.258 & 0.502 & -0.105 \\
\hline $\mathrm{Mn}, \mathrm{mg} / \mathrm{kg}$ & PV19 & 0.768 & 0.153 & 0.133 & 0.320 & 0.228 & 0.324 \\
\hline $\mathrm{Fe}, \mathrm{mg} / \mathrm{kg}$ & PV20 & 0.132 & 0.659 & 0.608 & 0.233 & -0.051 & -0.022 \\
\hline $\mathrm{Ni}, \mathrm{mg} / \mathrm{kg}$ & PV21 & 0.321 & 0.707 & 0.508 & 0.182 & 0.053 & 0.039 \\
\hline $\mathrm{Cu}, \mathrm{mg} / \mathrm{kg}$ & PV22 & 0.683 & 0.468 & 0.248 & 0.093 & 0.302 & -0.143 \\
\hline $\mathrm{Zn}, \mathrm{mg} / \mathrm{kg}$ & PV23 & 0.943 & 0.153 & -0.125 & 0.065 & 0.058 & -0.059 \\
\hline $\mathrm{Cd}, \mathrm{mg} / \mathrm{kg}$ & PV24 & 0.936 & 0.085 & -0.050 & -0.130 & -0.139 & -0.115 \\
\hline $\mathrm{Pb}, \mathrm{mg} / \mathrm{kg}$ & PV25 & 0.938 & 0.158 & -0.090 & 0.088 & -0.010 & -0.124 \\
\hline
\end{tabular}

The peat humification process was examined using van Krevelen graphs frequently applied for the analysis of carbon biogeochemical cycle and genesis of fossil fuel (Van Krevelen, 1950). Table 6 shows the elemental ratios of the studied peat samples. According to Steelink (1985), the atomic ratios $\mathrm{O} / \mathrm{C}, \mathrm{H} / \mathrm{C}$, and $\mathrm{N} / \mathrm{C}$ indices are useful in the identification of structural changes and the degree of maturity of peat in different depositional environments. The graph of $\mathrm{H} / \mathrm{C}$ atomic ratio versus $\mathrm{O} / \mathrm{C}$ atomic ratio reveals changes in the properties associated with coalification reactions.

Figure 2 shows the relation between $\mathrm{H} / \mathrm{C}$ atomic ratio and $\mathrm{O} / \mathrm{C}$ atomic ratio of organic material of a differing decomposition degree-beginning with bog plants up to brown coal, lignite, and coal. The graph in Fig. 2 could be considered as a graphical statistical representation of humification process, indicating the degree of maturity and intensity of degradation processes such as dehydrogenation (reduction of $\mathrm{H} / \mathrm{C}$ ratio), decarboxylation (reduction of $\mathrm{O} / \mathrm{C}$ ratio), demethylation occurring during the decay of peat-forming plants, and peat maturation continuing up to coal. These changes are especially evident when atomic ratios of peatforming plants are compared to the atomic ratio of organic matter of a high decomposition degree (low moor peat, 
ELEMENTAL RATIOS AND HUMIFICATION COEFFICIENTS OF PEAT

\begin{tabular}{|c|c|c|c|c|c|c|c|c|c|c|c|c|}
\hline Sample & $\mathrm{H} / \mathrm{C}$ & $\mathrm{N} / \mathrm{C}$ & $\mathrm{O} / \mathrm{C}$ & $\mathrm{E}_{2 /} \mathrm{E}_{6}$ & $\mathrm{E}_{4} / \mathrm{E}_{6}$ & $\mathrm{E}_{2} / \mathrm{E}_{3}$ & $\mathrm{E}_{3} / \mathrm{E}_{4}$ & PHI & $\mathrm{HI}$ & $\mathrm{K}$ & PyI & HD \\
\hline Ploce $0-30$ & 1.216 & 0.023 & 0.558 & 24.100 & 2.700 & 2.060 & 4.333 & 18.139 & 0.113 & 0.534 & 31.6 & 1.014 \\
\hline Ploce 30-60 & 1.258 & 0.017 & 0.501 & 22.000 & 2.600 & 2.056 & 4.115 & 27.507 & 0.155 & 0.515 & 18.2 & 0.942 \\
\hline Ploce 60-85 & 1.312 & 0.011 & 0.677 & 15.875 & 2.000 & 2.082 & 3.813 & 35.362 & 0.140 & 0.636 & 16.6 & 1.055 \\
\hline Ploce 85-110 & 1.207 & 0.017 & 0.571 & 17.833 & 2.000 & 2.058 & 4.333 & 31.742 & 0.134 & 0.290 & 13.8 & 0.994 \\
\hline Ploce $110-130$ & 1.179 & 0.013 & 0.586 & 18.600 & 2.760 & 1.938 & 3.478 & 39.033 & 0.139 & 0.307 & 15.3 & 1.102 \\
\hline Gāgu 0-20 & 1.359 & 0.020 & 0.631 & 10.438 & 1.813 & 1.942 & 2.966 & 27.007 & 0.142 & 0.971 & 16.2 & 1.029 \\
\hline Gāgu 20-40 & 1.376 & 0.016 & 0.658 & 15.778 & 2.167 & 1.986 & 3.667 & 52.431 & 0.150 & 0.424 & 16.8 & 1.107 \\
\hline Gāgu 40-60 & 1.368 & 0.013 & 0.674 & 12.313 & 1.875 & 1.931 & 3.400 & 66.310 & 0.171 & 0.400 & 39.1 & 1.124 \\
\hline Gāgu 60-80 & 1.383 & 0.012 & 0.692 & 12.071 & 1.929 & 1.920 & 3.259 & 63.467 & 0.195 & 0.609 & 39.0 & 1.214 \\
\hline Gāgu 80-100 & 1.330 & 0.014 & 0.657 & 13.222 & 2.056 & 1.935 & 3.324 & 48.207 & 0.171 & 0.474 & 21.7 & 1.168 \\
\hline Gāgu 100-120 & 1.317 & 0.013 & 0.653 & 15.955 & 2.273 & 2.006 & 3.500 & 39.179 & 0.191 & 0.305 & 19.7 & 1.048 \\
\hline Gāgu 120-140 & 1.313 & 0.014 & 0.622 & 19.095 & 2.476 & 1.985 & 3.885 & 33.268 & 0.125 & 0.307 & 15.8 & 1.059 \\
\hline Kaigu 0-25 & 1.421 & 0.020 & 0.647 & 11.444 & 1.889 & 1.943 & 3.118 & 7.042 & 0.070 & 0.946 & 21.9 & 1.182 \\
\hline Kaigu 25-45 & 1.391 & 0.015 & 0.661 & 10.526 & 1.842 & 1.923 & 2.971 & 12.334 & 0.122 & 0.271 & 12.1 & 1.106 \\
\hline Kaigu $45-70$ & 1.373 & 0.014 & 0.654 & 16.250 & 2.125 & 1.970 & 3.882 & 7.992 & 0.083 & 0.188 & 14.7 & 1.113 \\
\hline Kaigu 70-95 & 1.431 & 0.015 & 0.680 & 24.091 & 2.727 & 2.008 & 4.400 & 7.228 & 0.068 & 0.191 & 11.5 & 1.187 \\
\hline Kaigu 95-125 & 1.372 & 0.014 & 0.687 & 16.571 & 2.000 & 2.035 & 4.071 & 6.442 & 0.072 & 0.209 & 9.1 & 1.187 \\
\hline Kaigu 125-145 & 1.417 & 0.014 & 0.930 & 29.500 & 2.700 & 1.916 & 5.704 & 1.670 & 0.067 & 0.323 & 10.8 & 1.348 \\
\hline Dižais Veiķenieks 0-25 & 1.372 & 0.011 & 0.741 & 24.300 & 2.650 & 1.876 & 4.887 & 27.909 & 0.314 & 0.804 & 45.5 & 1.170 \\
\hline Dižais Veiķenieks 25-52 & 1.368 & 0.012 & 0.699 & 11.947 & 1.737 & 2.009 & 3.424 & 69.336 & 0.404 & 0.721 & 24.1 & 1.123 \\
\hline Dižais Veik̦enieks 52-75 & 1.383 & 0.008 & 0.724 & 13.308 & 2.000 & 2.012 & 3.308 & 89.385 & 0.298 & 0.843 & 24.7 & 1.144 \\
\hline Dižais Veiķenieks 75-98 & 1.369 & 0.008 & 0.744 & 12.083 & 1.833 & 1.986 & 3.318 & 199.601 & 0.406 & 1.277 & 27.7 & 1.157 \\
\hline Dižais Veiķ,enieks 98-118 & 1.395 & 0.008 & 0.754 & 17.750 & 2.375 & 2.014 & 3.711 & 126.397 & 0.349 & 1.177 & 22.7 & 1.206 \\
\hline Mazais Veiķenieks 0-30 & 1.473 & 0.014 & 0.770 & 16.167 & 1.667 & 2.021 & 4.800 & 23.807 & 0.087 & 0.814 & 19.2 & 1.184 \\
\hline Mazais Veikenieks 30-60 & 1.488 & 0.010 & 0.741 & 12.667 & 1.500 & 2.000 & 4.222 & 10.220 & 0.077 & 0.610 & 17.6 & 1.237 \\
\hline Mazais Veiķenieks 60-90 & 1.398 & 0.031 & 0.532 & 26.333 & 2.667 & 2.079 & 4.750 & 2.984 & 0.069 & 0.326 & 39.1 & 1.055 \\
\hline Mazais Veiķenieks 90-125 & 1.369 & 0.038 & 0.501 & 23.182 & 2.727 & 2.056 & 4.133 & 2.485 & 0.071 & 0.545 & 36.6 & 1.035 \\
\hline
\end{tabular}

coal). From the point of view of chemistry, humification can be considered as a process in which more labile structures (carbohydrates, amino acids, etc.) are destroyed, but thermodynamically more stable aromatic and polyaromatic structures emerge. It follows that the atomic ratios are associated with the processes transpiring during peat humification. As shown in Figure 2, H/C ratio decreases with increasing decomposition degree of the original living matter,

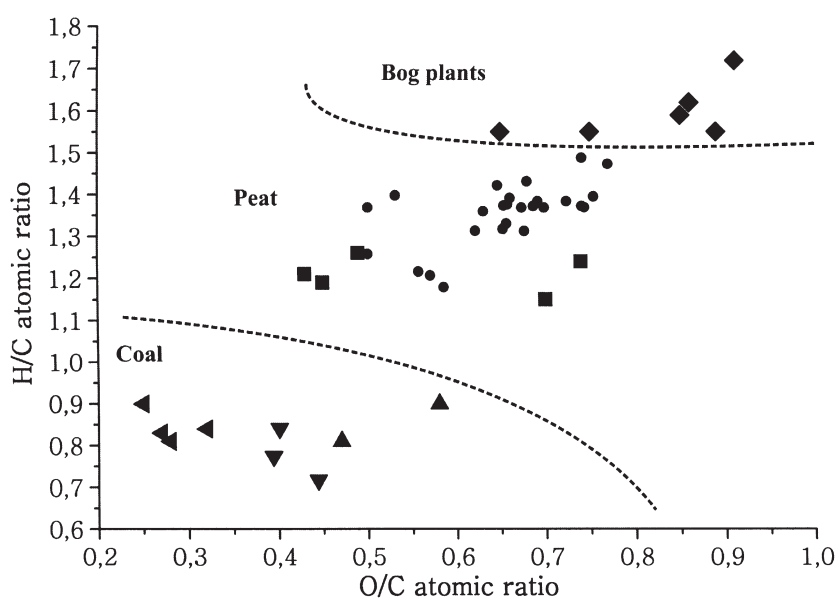

Fig. 2. Van Krevelen (H/C vs. O/C atomic ratio) graph of bog plants ( $)$ peat samples from studied bogs in Latvia $(\bullet)$, reference peat samples (IHSS) and peat samples from common peat bogs $(\boldsymbol{\square})$, brown coal $(\mathbf{\Lambda})$, coal $(\mathbf{4})$, lignite $(\boldsymbol{\nabla})$ starting with peat-forming plants, cellulose, and proteins, and up to bituminous coal. Comparatively, the studied peats are at the start of the transformation process of living organic matter. The van Krevelen graph (Fig. 2) also indicates a decrease in $\mathrm{O} / \mathrm{C}$ ratio, illustrating the decrease in the amount of oxygen-containing functional groups, such as methoxyl, carboxylic, and carbonyl functional groups, in the fossil material with increasing humification degree. In order to provide reliable and quantity information about the early diagenesis, we carried out further studies of the dependence of the elemental composition of the peat samples on their age (depth and decomposition degree (Fig. 3).

$\mathrm{H} / \mathrm{C}$ value showed a negative relation with peat depth; Kaigu and Mazais Veikenieks peat bogs had the highest negative correlations. However, Dižais Veikenieks bog showed a strong positive relation. This demonstrates that atomic ratio cannot be correctly used to study the humification process due to the significant impact of the original plant composition and peat formation conditions.

Changes of carbohydrate concentration in peat correlate more strongly with peat depth and, evidently, peat age (Fig. 4). The carbohydrate concentration in peat decreased with depth of the studied peat layers (Fig. 4) clearly indicating that carbohydrate degradation is amongst the major processes describing peat formation and humification. 


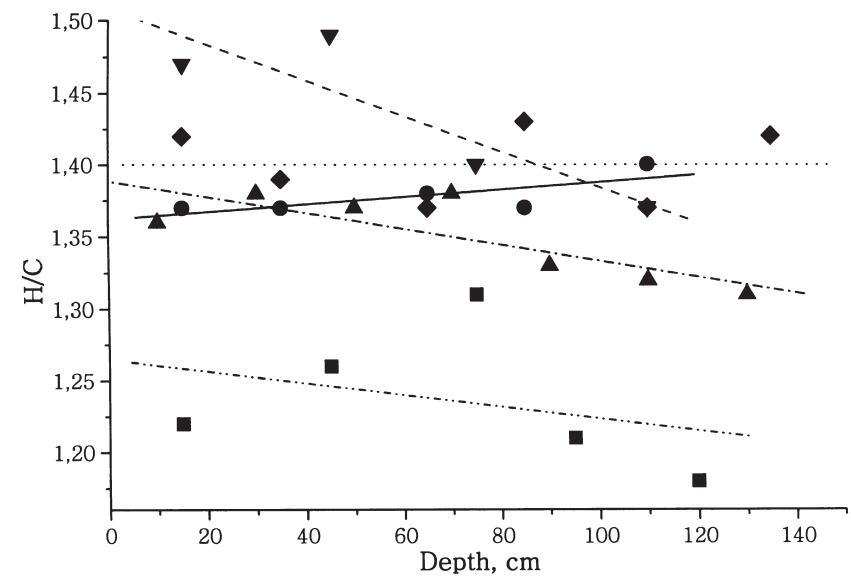

Fig. 3. Dependence of $\mathrm{H} / \mathrm{C}$ value of peat depth in different peat bogs.

- Dižais Veiķenieks peat bog $\left(-\mathrm{Y}=1.362+2.543^{-4} \cdot \mathrm{X} ; \mathrm{R}=0.742\right)$ $P>0.05$

$\Delta$ Gāgu peat bog $\left(-\cdots \cdot \mathrm{Y}=1.389-5.536^{-4} \cdot \mathrm{X} ; \mathrm{R}=-0.195\right) P>0.02$

- Kaigu peat bog (…..... $\left.\mathrm{Y}=1.400-4.892^{-6} \cdot \mathrm{X} ; \mathrm{R}=-0.812\right) P>0.05$

Ploce peat bog $\left(-\cdots \mathrm{Y}=1.265-4.118^{-4} \cdot \mathrm{X} ; \mathrm{R}=-0.338\right) P>0.05$

$\boldsymbol{\nabla}$ Mazais Veiķenieks peat bog $(---\mathrm{Y}=1.509-0.001 \cdot \mathrm{X} ; \mathrm{R}=-0.889)$ $P>0.05$

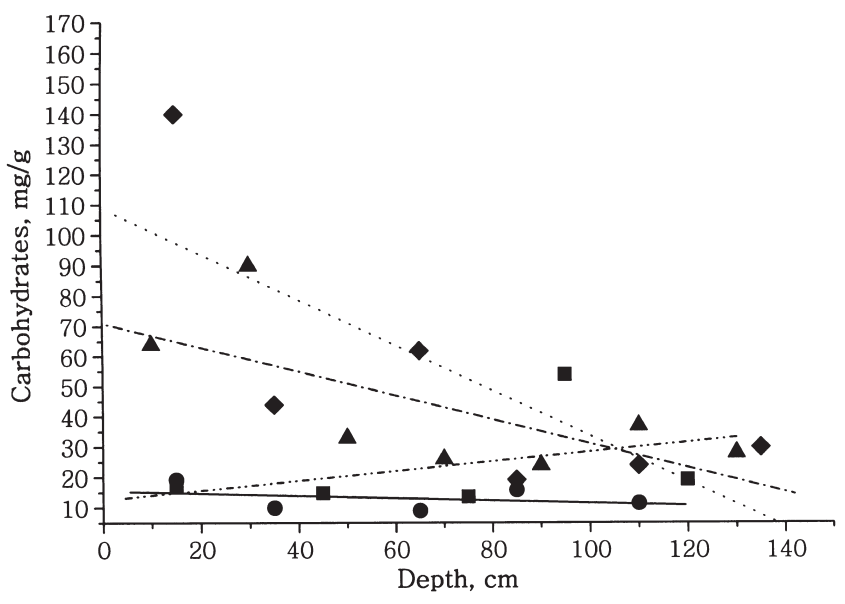

Fig. 4. Relationship between carbohydrate concentration and peat depth in different peat bogs.

- Dižais Veikenieks peat bog $(-\mathrm{Y}=15.599-0.041 \cdot \mathrm{X} ; \mathrm{R}=-0.356)$ $P>0.05$

$\Delta$ Gāgu peat bog $(-\cdot-\mathrm{Y}=71.018-0.398 \cdot \mathrm{X} ; \mathrm{R}=-0.697)^{*} P>0.05$

- Kaigu peat bog $(\cdots \cdots \cdots . . . \mathrm{Y}=108.944-0.752 \cdot \mathrm{X} ; \mathrm{R}=-0.751) P>0.05$

Ploce peat bog $(-\cdots \mathrm{Y}=12.521+0.159 \cdot \mathrm{X} ; \mathrm{R}=-0.338) P>0.05$

Variability of the 25 parameters, describing peat properties, their decomposition degree, age, and peat humification process were examined using principal component analysis. The first five components extracted explained $84 \%$ of the total variance (Table 7). The first component involved parameters describing the development of peat-its elemental composition ( $\mathrm{C}, \mathrm{N}$ and $\mathrm{O}$ ) and correlated well with the suggested humification degree HD. The second component characterised the correlation between peat type, hydrogen,
Table 7

SUMMARY STATISTICS OF PCA ANALYSIS OF THE DATA ON THE SELECTED PEAT PROPERTIES AND HUMIFICATION COEFFICIENTS

\begin{tabular}{c|c|c|c}
\hline Component & Variance & $\begin{array}{c}\text { \% of explained } \\
\text { variance }\end{array}$ & $\begin{array}{c}\text { Cumulative \% of } \\
\text { variance }\end{array}$ \\
\hline 1 & 6.582 & 34.641 & 34.641 \\
2 & 3.201 & 16.847 & 51.489 \\
3 & 3.137 & 16.509 & 67.998 \\
4 & 1.945 & 10.239 & 78.237 \\
5 & 1.091 & 5.742 & 83.979
\end{tabular}

Table 8

LOADING STRUCTURE OF THE FIRST FIVE COMPONENTS EXTRACTED BY PCA ANALYSIS OF THE DATA ON THE SELECTED PEAT PROPERTIES AND HUMIFICATION COEFFICIENTS

\begin{tabular}{lc|c|c|c|c|c}
\hline \multicolumn{2}{c}{ Variable/acronyme } & \multicolumn{5}{c}{ Component } \\
\cline { 3 - 7 } & & 1 & 2 & 3 & 4 & 5 \\
\hline Type & HV1 & -0.095 & 0.836 & -0.268 & 0.093 & 0.031 \\
Depth, cm & HV2 & 0.069 & 0.095 & 0.077 & 0.159 & 0.913 \\
C,\% & HV3 & -0.939 & 0.236 & -0.063 & 0.010 & 0.105 \\
$\mathrm{H}, \%$ & HV4 & -0.158 & 0.866 & -0.028 & -0.136 & -0.255 \\
N,\% & HV5 & -0.545 & 0.600 & -0.217 & 0.433 & -0.115 \\
S,\% & HV6 & -0.061 & 0.516 & -0.108 & 0.123 & 0.111 \\
O,\% & HV7 & 0.906 & -0.322 & 0.143 & -0.151 & 0.101 \\
H/C & HV8 & 0.770 & 0.487 & 0.020 & -0.125 & -0.313 \\
N/C & HV9 & -0.482 & 0.600 & -0.249 & 0.452 & -0.138 \\
O/C & HV10 & 0.937 & -0.296 & 0.094 & -0.043 & 0.041 \\
Age, years & HV11 & -0.069 & -0.227 & -0.325 & 0.139 & 0.816 \\
$\mathrm{E}_{2 /} \mathrm{E}_{6}$ & HV12 & -0.044 & 0.050 & -0.214 & 0.853 & 0.271 \\
$\mathrm{E}_{4 /} \mathrm{E}_{6}$ & HV13 & -0.276 & 0.028 & -0.067 & 0.803 & 0.394 \\
HI & HV14 & 0.085 & -0.232 & 0.889 & -0.276 & 0.146 \\
PHI & HV15 & 0.093 & -0.343 & 0.860 & -0.082 & -0.078 \\
K & HV16 & 0.197 & -0.112 & 0.700 & -0.086 & -0.436 \\
PyI & HV17 & -0.143 & 0.152 & 0.530 & 0.462 & -0.456 \\
HD & HV18 & -0.471 & -0.180 & 0.079 & -0.627 & 0.247
\end{tabular}

and nitrogen; these parameters are correlated with peat humification index PHI. The third component characterised the humification processes, as it was associated with most of the humification coefficients used in our study. Association of peat age and type with the component was also suggested. It is supposed that all the used humification coefficients can be applied for analysis of peat humification process since each of them describes differing aspects of the humification process. The fourth component was characterised by a close relation between the extinction ratios of humic extracts; it rather described the properties of peat humic matter than the transformation degree of peat organic matter. However, the very simple parameter-extinction ratio $E_{4} / E_{6}$ is well correlated with the depth of the location of the peat samples and peat age; it can also be efficiently used to analyse the humification process. The fifth component can be designated as the "age component" since it is correlated with peat depth, age and humification indicators such as $\mathrm{E}_{4} / \mathrm{E}_{6}, \mathrm{H} / \mathrm{C}, \mathrm{K}, \mathrm{PyI}$, and HD. Therefore, these humification indicators can be recommended for characterisation of the peat humification process (Fig. 5, 6). 


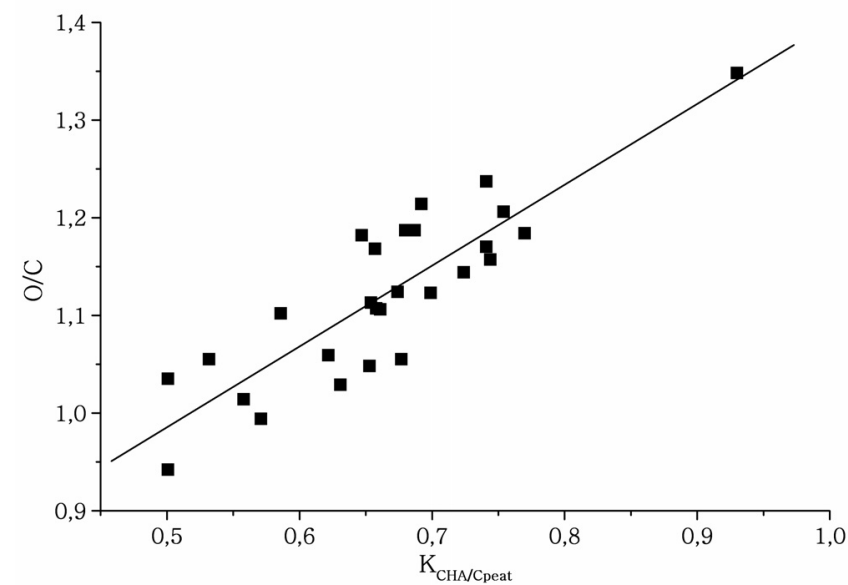

Fig. 5. Dependence of $\mathrm{O} / \mathrm{C}$ values on $\mathrm{K}_{\mathrm{CHA} / \text { Cpeat }}$ $(\mathrm{Y}=0.572+0.828 \cdot \mathrm{X} ; \mathrm{R}=0.863) * * P<0.0001$

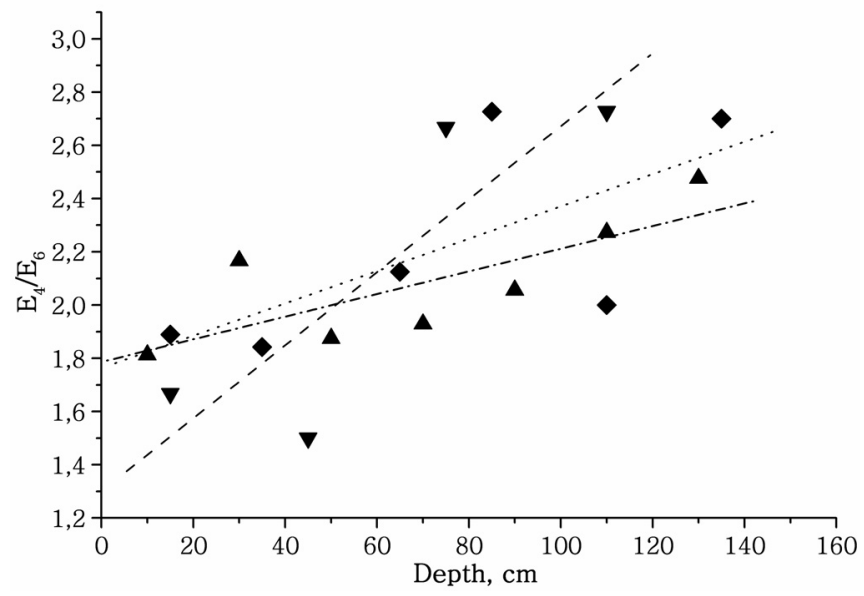

Fig. 6. Dependence of $\mathrm{E}_{4} / \mathrm{E}_{6}$ values on peat depth in different peat bogs

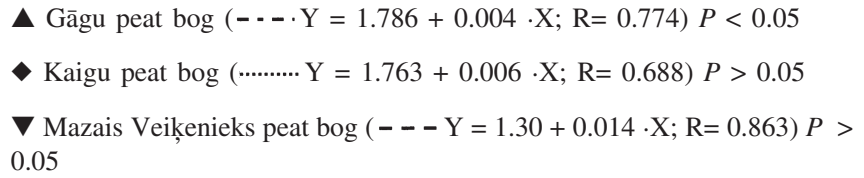

The peat age, depth, and the suggested humification indicators are located closely in the 3D space of the first three components obtained using PCA analysis (Fig. 7). Other parameters, such as $\mathrm{H} / \mathrm{C}$ ratio and $\mathrm{E}_{4} / \mathrm{E}_{6}$ ratio (Fig. 7), also grouping with peat age. These variabilities reflect the formation conditions of peat.

Humification has been mostly studied with the aim to analyse composting and soil formation processes. However, the humification process in peat very much differs from that in composts and soils in a quite rapid decomposition of organic matter in early humification stages. In water, under the impact of the anaerobic and acidic environment, the humification process of the saturated peat layers is very much retarded. Nevertheless, in peat it is possible to follow the humification for very long periods (several thousand years are not the limit). The obtained results demonstrate

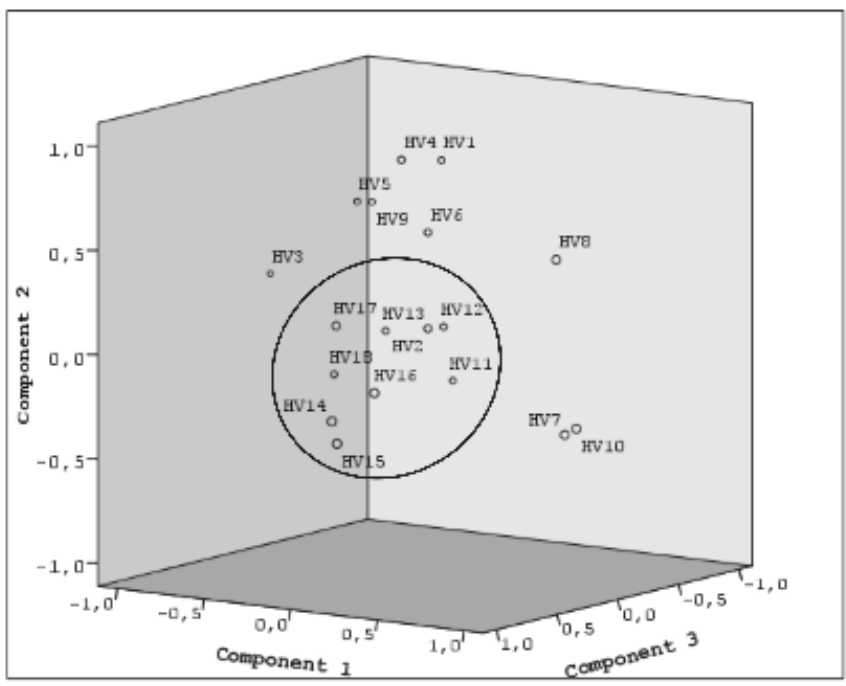

Fig. 7. Ordination of variables representing selected peat properties and humification coefficients on the first three PCA axes.

that it is possible to study the stage of humification of organic matter in peat according to its age and apply the suggested methods of analysis to the estimation of peat humification degree (peat humification indexes).

The first question to be resolved is the definition of the concepts "decomposition degree" and "humification degree". The decomposition degree describes the extent to which original (living) organic matter is transformed. The decomposition process thus includes: a) transformation processes of living organisms and their tissues; b) degradation of molecules forming a living organism; c) mineralisation (transformation of organic carbon compounds containing organic nitrogen, phosphorous, and sulphur compounds into their inorganic species); and d) formation of refractory organic substances-humic substances. Decomposition can also be described as the breakdown of plant material by microorganisms that use decaying organic matter as a source of energy and building material. Besides chemical decomposition, an important indicator of decomposition is mechanical friction. The decomposition degree is one of the key parameters describing the use of peat for agricultural purposes, several schemes for the characterisation of decomposition are suggested, such as von Post scale, $r$ value, and the peat classification of International Peat Society (Fuchsman, 1980).

The estimation of the humification degree is often based on the monitoring of humic substances (HS), humic acids (HA), and fulvic acids (FA), isolated by extraction in alkaline solution (Stevenson, 1994). Among the proposed indexes of maturity, those most representative of the evolution of the maturity of the compost were presented, particularly indexes measuring the evolution of HA compared to fulvic fraction or FA. Humification is a narrower concept, describing the development of humus (humic substances). As humification degree we suggest to use the ratio 
of the total amount of organic matter to the amount of formed humic substances:

$H D=\frac{C_{H S}}{C_{\text {peat }}}$.

As the results of our study show, this parameter corresponds well to the peat depth and age, so it can also be used to study the transformation processes of organic matter.

\section{ACKNOWLEDGEMENTS}

The authors are grateful to Dr. Enn Kaup (Institute of Geology, Estonia) for the determination of peat age using ${ }^{14} \mathrm{C}$ analysis, A. Dinkite (Balt-Ost Geo) for the analysis of botanical composition and decomposition degree. We thank the European Social fund for financial support to J. Šire.

\section{REFERENCES}

Baran, A. (2002) Characterization of Carex peat using extinction values of humic acids. Bioresource Technol., 85, 99-101.

Cavani, L., Ciavatta, C., Gessa, C. (2003) Identification of organic matter from peat, leonardite and lignite fertilisers using humification parameters and electrofocussing. Bioresource Technol., 86, 45-52.

Chaplin, M.F., Kennedy, J.F. (1994) Carbohydrate Analysis: a Practical Approach. London: Oxford University Press, pp. 32-33.

Chen, Y., Senesi, N., Schnitzer, M. (1977) Information provided on humic substances by $\mathrm{E}_{4} / \mathrm{E}_{6}$ ratios. Soil Sci. Soc. Amer. J., 41(2), 352-358.

Corvasce, M., Zsolnay, A., D’Orazio, V., Lopez, R., Miano, T.M. (2006) Characterization of water-extractable organic matter in a deep soil profile. Chemosphere, 62, 1583-1590.

Domeizel, M., Khalil, A., Prudent, P. (2004) UV spectroscopy: a tool for monitoring humification and for proposing an index of the maturity of compost. Bioresource Technol., 94, 177-184.

Francioso, O., Ciavatta, C., Montecchio, D., Tugnoli, V., Sanchez-Cortes, S., Gessa, C. (2003) Quantitative estimation of peat, brown coal and lignite humic acids using chemical parameters, ${ }^{1} \mathrm{H}-\mathrm{NMR}$ and DTA analyses. Bioresource Technol., 88, 189-195.

Fuchsman, C.H. (1980) Peat: Industrial Chemistry and Technology. Academic Press: N.Y. 279 pp.

Hargitai, L. (1994) Biochemical transformation of humic substances during humification related to their environmental functions. Environ. Internat., 20(1), 43-48.

Ikeya, K., Watanabe, A. (2003) Direct expression of an index for the degree of humification of humic acids using organic carbon concentration. Soil Sci. Plant Nutr., 49(1), 47-53.

Jerzykiewicz, M., Drozd, J., Jezierski, A. (1999) Organic radicals and paramagnetic metal complexes in municipal solid waste composts. An EPR and chemical study. Chemosphere, 39(2), 253-268.
Lu, X.Q., Hanna, J.V., Johnson, W.D. (2001) Evidence of chemical pathways of humification: a study of aquatic humic substances heated at various temperatures. Chem. Geol., 177, 249-264.

Lu, X.Q., Hanna, J.V., Johnson, W.D., 2000. Source indicators of humic substances: An elemental composition, solid state 13C NMR and Py-GC-MS study. Appl. Geochem., 15, 1019-1033.

Lukoshko, E.S., Bambalov, N.N., Khoruznik, A.V., Striguikii, V.P., Dudarchik, V.M. (1988) Composition and properties of the humic acids of the initial period of peat formation. Khim. Tverdogo Topliva, 22(5), 3-10.

Milori, D.M.B.P., Neto, L.M., Bayer, C., Mielniczuk, J., Bagnato, V.S. (2002) Humification degree of soil humic acids determined by fluorescence spectroscopy. Soil Sci., 167(11), 739-749.

Perez, M.G., Martin-Neto, L., Saab, S.C., Novotny, E.H., Milori, D.M.B.P., Bagnato, V.S., Colnago, L.A., Melo, W.J., Knicker, H. (2004) Characterization of humic acids from a Brazilian oxisol under different tillage systems by EPR, ${ }^{13} \mathrm{C}$ NMR, FTIR and fluorescence spectroscopy. Geoderma, 118, 181-190.

Piccolo, A. (2001) The supramolecular structure of humic substances. Soil Sci., 166(11), 810-832.

Preston, C.M., Axelson, D.E., Levesque, M., Mathur, S.P., Dinel, H., Dudley, R.L. (1989) Carbon 13 NMR and chemical characterization of particle size separates of peats differing in degree of decomposition. Org. Geochem., 14(4), 393-403.

Rosa, A.H., Simoes, M.L., de Oliveira, L.C., Rocha, J.C., Neto, L.M., Milori, D.M.B.P. (2005) Multimethod study of the degree of humification of humic substances extracted from different tropical soil profiles in Brazil's Amazonian region. Geoderma, 127, 1-10.

Schimel, D.S., Braswell, B.H., Parton, W.J. (1997) Equilibration of the terrestrial water, nitrogen and carbon cycles. Proc. Natl. Acad. Sci. USA, 94(16), 8280-8283.

Schnitzer, M., Levesque, M. (1979) Electron spin resonance as a guide to the degree of humification of peats. Soil Sci., 127(3), 140-145.

Steelink, C. (1985) Implications of elemental characteristics of humic substances. In Aiken, G.R., McKnight, D.M., Wershow, R.L., MacCarthy, P. (eds.). Humic Substances in Soil, Sediment, and Water (pp. 457-476). New York: Wiley.

Stevenson, F.J. (1994) Humus Chemistry: Genesis, Composition, Reactions. $2^{\text {nd }}$ ed. New York: Wiley. 496 pp.

Tan, K.H. (2005) Soil Sampling, Preparation, and Analysis. $2^{\text {nd }}$ ed. New York: Taylor \& Francis group. 623 pp.

Van Krevelen, D.W. (1950) Graphical statistical method for the study of structure and reaction processes of coal. Fuel, 29, 269-284.

Von Post, L. (1924) Das genetische System der Organogenen Bildungen Schwedens. In Memoires sur la nomenclature et la classification des sols. International Committee of Soil Science, Helsinki, pp. 287-304.

Zsolnay, A., Baigar, E., Jimenez, M., Steinweg, B., Saccomandi, F. (1999) Differentiating with fluorescence spectroscopy the sources of dissolved organic matter in soils subjected to drying. Chemosphere, 38(1), 45-50.

Лиштван, И.И., Король, Н.Т. (1975) Основные свойства торфа и методы их определения [Basic Properties of Peat and Methods for Their Determination]. Минск: Наука и техника. 320 с. (in Russian).

Received 3 October 2007

\section{KŪDRAS HUMIFIKĀCIJAS INDIKATORI: EKSPERIMENTĀLA ANALĪZE}

Svarīgi augšņu, kūdras un fosilo oglekli saturošu nogulumu organiskās vielas raksturlielumi ir to sadalīšanās pakāpe, kas raksturo sākotnējās biomasas pārveidošanās intensitāti, un humifikācijas pakāpe, kas raksturo jaunu organisko vielu - humusvielu veidošanās tempu no sākotnējās dzīvās vielas. Šajā rakstā ir pētītas un salīdzinātas humifikācijas analīzes metodes pilnīgi analizētām un datētām $\left({ }^{14} \mathrm{C}\right)$ kūdras kolonnām no vairākiem Latvijas purviem. Ieteikts humifikācijas pakāpi definēt kā kopējās organiskās vielas kūdrā un humifikācijas gaitā veidoto humusvielu attiecību. 